\begin{tabular}{c} 
International Journal of Advanced Chemistry, 2(2)(2014) 74-79 \\
International Journal of Advanced Chemistry \\
Journal home page: $\begin{array}{c}\text { www.sciencepubco.com/index.php/IJAC } \\
\text { doi: } 10.14419 / \text { ijac.v2i2.2619 } \\
\text { Research Paper }\end{array}$ \\
\hline
\end{tabular}

\title{
Development and validation of UV spectrophotometric method for simultaneous estimation of nitrate and nitrite in water, soil, drug and vegetable samples
}

\author{
Kanchan Nemade*, Sanjay Attarde \\ School of Environmental \& Earth Sciences, North Maharashtra University, Jalgaon - 425001 (MS) India \\ *Corresponding author E-mail: dhanshreeingale75@gmail.com
}

\begin{abstract}
A sensitive and specific spectrophotometric method has been developed for the simultaneous determination of nitrate and nitrite at trace levels. The proposed method is based on diazotization of nitrite with a pharmaceutical compound-metoclopramide (4-amino-5-chloro- $N$ (2-(diethylamino)ethyl)- 2-methoxybenzamide) in acid medium to form diazonium ion which is coupled with ethyl acetoacetate (EAA) in basic medium to form azo dye, showing absorption maxima at $437.5 \mathrm{~nm}$. Different variables affecting the reactions are optimized. The method is precise and accurate and has been applied to water, soil, drug and vegetable samples. The results of the investigated method using metoclopramide were compared with available official literature method. The results obtained by the proposed method agree well with the standard established method.
\end{abstract}

Keywords: Diazotization, Nitrate and Nitrite, Spectrophotometric Estimation.

\section{Introduction}

Nitrate and Nitrite anions occur widely in natural system. Both species are produced in the nitrification process in which ammonia is oxidized by certain soil bacteria. Under anaerobic condition, nitrate reduces to nitrite then to $\mathrm{NO}, \mathrm{N}_{2} \mathrm{O}$ and $\mathrm{N}_{2}$ by the process of denitrification (Liang et al. 1994, Gray \& Stephen 2001). Nitrites are mainly used as a food preservative. Nitrite, and in some cases nitrate, are functional food ingredients that serve as effective antimicrobials to inhibit Clostridium botulinum and Listeria monocytogenes growth, impart a distinctive cure color to meat products, provide antioxidant properties to retard lipid oxidation and extend the shelf-life of these products (Cassens 1995, Cassens 1997, Cassens 1999). Nitrite combines with myoglobin to form nitrosohaemoglobin, which is responsible for characteristic red color in cured meat and hence sometimes used as meat preservative (Ignarro \& et al 1993). Nitric oxide, a reactive radical gas, controls various vital physiological functions in the body. This small inorganic molecule plays a variety of roles such as maintenance of vascular tone, neurotransmission, and host defense by destroying microbes (Nathan 1992). Nitrite reacts with secondary amines in the living body and is indicated to form carcinogenic $\mathrm{N}$ nitrosamine. Furthermore, it is oxidized to nitrate by the dissolved oxygen in water, this decreasing the oxygen content of water (Patty 1963). Primary sources of organic nitrates in the environment include human sewage and livestock manure (EPA 1931). Fertilizers provide the sources of inorganic nitrates in the environment include potassium nitrate and ammonium nitrate, which may leach to ground water and contaminate private residential drinking water wells (EPA 1931, WHO 2006).A few studies have reported other health effects that are possibly associated with nitrate exposure in children, including increased incidence of childhood diabetes, recurrent diarrhea, and recurrent respiratory tract infections. Other reported effects of chronic exposure reported in adults include frequent urination and spleen hemorrhaging (bleeding). Acute high dose ingestion exposure to nitrates can cause abdominal pain, muscle weakness, blood in stools and urine, fainting, and death. Likely exposure pathways for children include ingesting contaminated drinking water, most commonly of concern for private wells (, Virtanen et al. 1994, Gupta et al. 2000, Gupta et al. 2001, EPA 2006). From these points of view, the determination of nitrate and nitrite in soil and water samples is of importance. Many methods have been reported for the determination of the nitrate and nitrite in water, soil and vegetable samples including flow injection analysis (Ali \& Kazemzadeh 1999, pp. 15-21), ion chromatography (Murad et al. 2000, pp. 433-437), high performance liquid chromatography (Hitoshi \& Shigeo 2009, pp. 3163-3167, Vincenzo et al. 1997, pp. 213-219), and capillary zone electrophoresis (CZE) using a high ionic strength electrolyte buffer (Keiichi et al. 1999, pp. 303-311). However, there are several disadvantages of above methods like, detection at low level (Ali \& Kazemzadeh 1999, pp. 15-21), needs centrifugation (Murad et al. 2000, pp. 433-437), requires long equilibration time for column (Vincenzo et al. 1997, pp. 213-219, Hitoshi \& Shigeo 2009, pp. 3163-3167), and needs high sensitivity detectors to improve LODs at low level (Keiichi et al. 1999, pp. 303-311). In the present work the authors have described a simple in-expensive and accurate UV Spectrophotometric method for the simultaneous determination of $\mathrm{NO}_{2}{ }^{-} \& \mathrm{NO}_{3}{ }^{-}$in water and vegetable samples.

\section{Materials and methods}

\subsection{Apparatus}


Spectral measurements were made with Shimadzu-1800 double beam spectrophotometer with $1.00 \mathrm{~cm}$ quartz cuvettes. A digital $\mathrm{pH}$ meter (model pH 5651, Electronic Corporation of India Ltd.) was used for the measurements of $\mathrm{pH}$. Electric balance (Type AUY 120 Shimadzu) was used for weighing the chemicals.

\subsection{Reagents}

All chemicals used were of analytical grade and metoclopramide reagent was provided from Genpharma International Pvt. Ltd., Pune, India. All water used was milli-Q water obtained from Millipore water purification system. Unless otherwise specified, all reagents used were of analytical reagent grade. Nitrate standard solutions and nitrite standard solutions were prepared from potassium nitrate (Anachemia, Montreal, Canada) and sodium nitrite (purity of $99.40 \%$, Fisher, Fair Lawn, USA), respectively.

Metoclopramide solution: A $0.1 \%$ solution of metoclopramide (4amino-5-chloro- $N$-(2-(diethylamino)ethyl)- 2-methoxybenzamide) was prepared by dissolving the requisite amount in milli-Q water and diluted up to mark in $100 \mathrm{ml}$ volumetric flask.

Ethyl acetoacetate (EAA) solution: $2 \%(\mathrm{w} / \mathrm{v})$ in milli-Q water Sulphanilamide $\& \mathrm{~N}$-(1-napthyl)-ethyenediamine dihydrochloride (NEDA) solution:

Added $105 \mathrm{~mL}$ concentrated $\mathrm{HCl}, 5.0$ gm sulphanilamide and 0.5 gm NEDA to $250 \mathrm{~mL}$ distilled water and stirred until dissolved. And added $136 \mathrm{gm}$ sodium acetate to it and stirred again until dissolved. The solution was diluted to $500 \mathrm{~mL}$ with distilled water and stored in dark. This solution was used as a buffered color reagent for reference method (Jain et al. 1990, pp. 69-75).

Nitrite solution: A $1000 \mathrm{mg} / \mathrm{L}$ nitrite solution was prepared by dissolving $0.1500 \mathrm{~g}$ sodium nitrite in $100 \mathrm{ml}$ water. More dilute solutions were prepared from this stock solution as required (Pisal Method 354.1, APHA 1995, AOAC, Method 36.1.21 1995).

Nitrate solution: A $1000 \mathrm{mg} / \mathrm{L}$ nitrate solution was prepared by dissolving $0.1631 \mathrm{~g}$ potassium nitrate in water. More dilute solutions were prepared from this stock solution as required (Pisal Method 354.1, APHA 1995, AOAC, Method 36.1.21 1995).

Solutions of Interfering Ions: Solutions of Inorganic ions $\mathrm{Cu}^{2+}$, $\mathrm{K}^{+}, \mathrm{Na}^{+}, \mathrm{Ca}^{2+}, \mathrm{Fe}^{3+}, \mathrm{Cl}^{-}, \mathrm{CO}_{3}{ }^{2-}, \mathrm{HPO}_{4}{ }^{2-}$ and $\left.\mathrm{SO}_{4}{ }^{2-}\right)$ were prepared from their appropriate A.R. grade water soluble salts (Christian 2001, p. 154).

\subsection{Proposed method}

To a series of $10 \mathrm{ml}$ volumetric flasks containing $0.01-0.4 \mathrm{mg} / \mathrm{L}$ of standard nitrite solution, $1 \mathrm{ml}$ of $0.5 \mathrm{M} \mathrm{HCl}$ and $0.5 \mathrm{ml} 0.1 \%$ metoclopramide were added and was shaken for $5 \mathrm{~min}$ to get diazonium ion. After that added $1.0 \mathrm{ml}$ of $2 \%$ ethyl acetoacetate as a coupling agent in basic medium using $2 \mathrm{ml}$ of $2 \mathrm{M}$ sodium hydroxide solution which then diluted to $10 \mathrm{ml}$ by milli-Q water. The colour developed was measured on spectrophotometer at wavelength $437.5 \mathrm{~nm}$. The concentration of nitrite was determined with the help of a standard calibration graph.

\subsection{Reference method}

To a series of $10 \mathrm{ml}$ volumetric flasks containing 0.01-0.4 mg/L of standard nitrite solutions, added $2.0 \mathrm{~mL}$ sulphanilamide-NEDA reagent solution and was shaken for 5 min and kept aside for 10 minutes. The absorbance was measured on spectrophotometer at wavelength $540 \mathrm{~nm}$. The concentration of nitrite was determined with the help of a standard calibration graph (Pisal Method 354.1).

\subsection{Determination of nitrite and nitrate in a mixture}

Suitable aliquots of nitrite and nitrate mixture at different mass ratios were taken separately in $10 \mathrm{ml}$ beakers and reduced the nitrate to nitrite with a pinch of granular mixture of zinc dust $/ \mathrm{NaCl}$ and conc. $\mathrm{HCl}$ (Biswas et al. 2004, pp. 308-312). Excess zinc dust was filtered and filtrate was used to determine the concentrations of total nitrate plus nitrite by following the proposed and reference procedures. The absorbance of equal volume of nitrite and nitrate mixture was measured without reduction of nitrate. This gives the conc. of nitrite originally present in the mixture. Subtracting this from the total gives the concentration of nitrate present in the mixture.

\subsection{Determination of nitrite and nitrate in environ- mental water samples}

The proposed method has been applied for the determination of nitrite and nitrate in Tap water and Reverse osmosis waste water samples. The interference of chloride was removed by precipitating the chloride with silver sulphate. Suitable aliquots were taken and analyzed for nitrite and nitrate following the proposed and reference methods (Nidal et al. 1999, pp. 819-826, Wang et al. 2000, p. 169).

\subsection{Determination of nitrite in soil samples}

About $1.0 \mathrm{~g}$ of soil sample was taken in a $25 \mathrm{~mL}$ beaker and extracted with $3 \mathrm{~mL}$ portions of $0.5 \%$ sodium carbonate solution. The extract was filtered through Whatman No. 41 filter paper (Bremner 1965, p. 1179). The filtrate was collected and diluted to $25 \mathrm{~mL}$. Appropriate aliquots of $1-2 \mathrm{~mL}$ of the solution were transferred in to a $10 \mathrm{~mL}$ calibrated flasks and analyzed according to the proposed procedure. They were tested negative. To these samples known amounts of nitrite and nitrate solutions were added and analyzed for nitrite and nitrate following the proposed and reference procedures.

\subsection{Nitrite determination in vegetable samples}

Vegetable samples were removed from their package and the outside leaves and/or ends of leaves and/or stems/stalks removed. Samples were rinsed in distilled, deionizer water, allowed to drain and the excess water spun off using a salad spinner (10 pumps of pressure, spun 30 secs). Rinsed samples were cut into smaller pieces and weighed to a mass $200 \mathrm{~g}$ sample. Sample pieces were placed in a food processor and homogenized $15 \mathrm{~s}$. The sides of the food processor were scraped and the sample homogenized an additional $15 \mathrm{~s}$. This process was repeated until the sample was homogenized for a total of $60 \mathrm{~s} \mathrm{(4} \mathrm{iterations).}$

\section{Results and discussion}

The maximum absorbance of the azo dye formed with $0.1 \%$ of metoclopramide in $2 \%$ Ethyl acetoacetate (EAA) was observed at $437.5 \mathrm{~nm}$. Such azo dye is found to be stable for at least 45 minutes permitting the measurement of absorbance.

\subsection{Factors affecting the absorbance spectrum}

\subsubsection{Effect of acidity}

In the present method hydrochloric acid provides a wide range of acidity for the maintenance of optimum $\mathrm{pH}$. The effect is studied for solutions containing fixed concentration of nitrite and by varying the concentration and volume of $\mathrm{HCl}$. The solutions were prepared as described in the proposed procedure. The results obtained showed that increasing the concentration of $\mathrm{HCl}$ leads to increase in absorbance and decreases the absorbance with increasing volume of $\mathrm{HCl}$. The absorbance was observed in the presence of 0.5$2.5 \mathrm{M}$ hydrochloric acid in a total $10.0 \mathrm{ml}$ of solution as shown in Fig.1. 


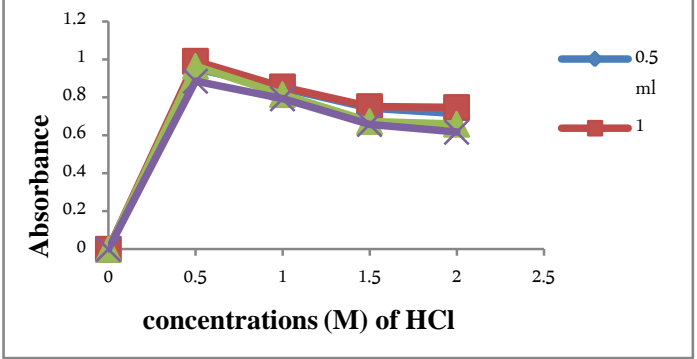

Fig. 1: Absorbance Variation with Varying Concentration and Volume of $\mathrm{HCl}$

The optimum concentration was fixed to be $0.5 \mathrm{M}$ and volume of $\mathrm{HCl}$ required was $1 \mathrm{~mL}$. This acidity was sufficient for protonation in diazotization reaction (Nagaraja et al. 2002).

\subsubsection{Effect of metoclopramide reagent concentration}

In order to fix the amount of metoclopramide concentration required for diazotization of nitrite and to achieve maximum absorbance, experiments were done by using different volumes $(0.5$ to $1 \mathrm{ml}$ ) of $0.1 \%$ of metoclopramide in the range of 0.05 to $0.1 \%$ to form diazonium salt. The results are presented in Fig. 2.

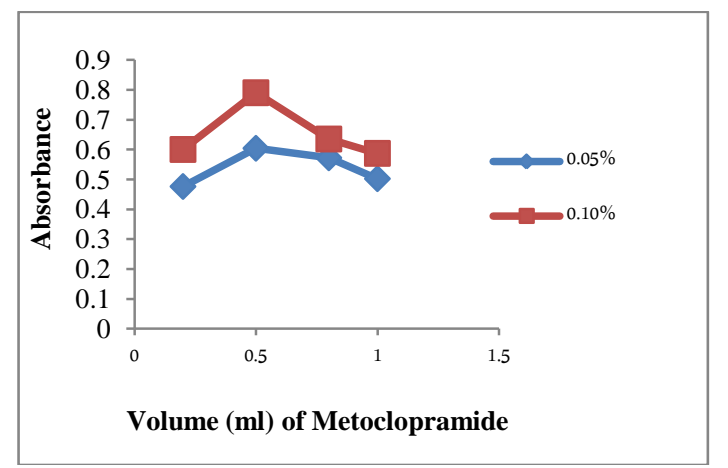

Fig. 2: Absorbance Variation with Varying Concentration of Nitrite and Volume of Metoclopramide Solutions

The maximum absorbance was observed for $0.5 \mathrm{~mL}$ of $0.1 \%$ metoclopramide solution. The colorless diazonium salt is very reactive and acts as an electrophile. Aryl diazonium cation undergoes electrophilic substitution reaction with coupling agent to produce an azo derivative (Pasha \& Narayana 2010, pp. 68-73, Sharma 2009).

\subsubsection{Effect of coupling agent concentration}

The amount of EAA solution required for maximum absorbance was examined. Experiments were done using 0.5-2.0 \% concentrations and $0.5-2.0 \mathrm{~mL}$ volumes of EAA solutions. The results are represented in Fig. 3.

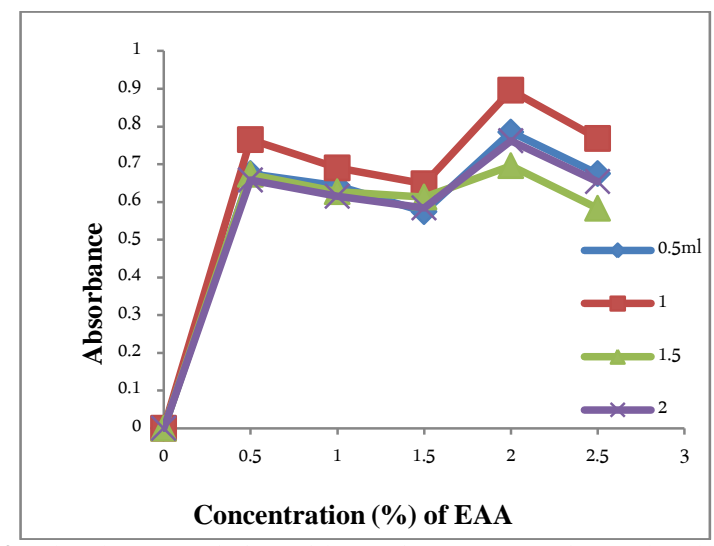

Fig. 3: Absorbance Variation with Varying Concentration and Volume of EAA Solutions
$1 \mathrm{ml}$ of $2 \%$ EAA was found enough to get maximum absorbance and was selected in all subsequent experiments. The diazonium cation couples with hydroxyl group of EAA in alkaline medium. The protons in EAA, alpha to carbonyl carbon are acidic and resulting carbanion undergo nucleophilic substitution. Enolate of EAA serves as a bidentate ligand, thus it forms yellow colored azo dye. Enolate anion of EAA is a strong nucleophile (Sharma 2009).

\subsubsection{Effect of base}

The effects of three diluents, $2 \mathrm{M}$ sodium hydroxide, distilled water and ethanol on stability of azo dye formed were studied with respect to time. The results are represented in Fig. 4.

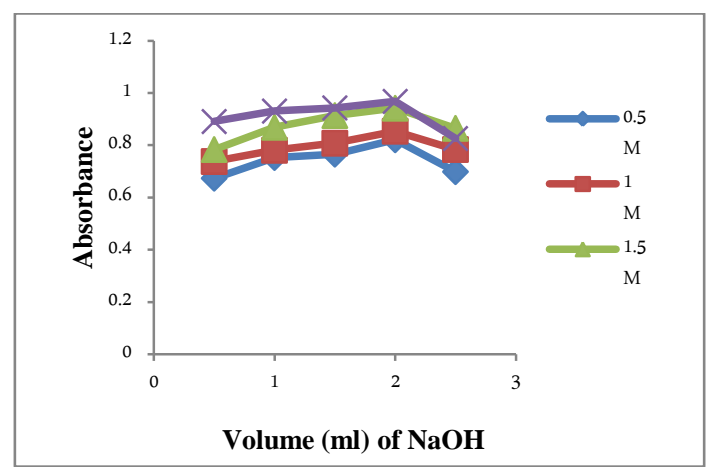

Fig. 4: Absorbance Variation with Varying Volume and Concentration of $\mathrm{NaOH}$ Solutions

It was observed from absorbance values that the color intensity and the stability maximum with $2 \mathrm{M} \mathrm{NaOH}$. The diazonium cation couples with hydroxyl group in EAA. Isomeric structure of compound changes with change in properties of solvent. Formed azo dye shows increased absorption in $\mathrm{NaOH}$ because percentage of enolic form increases (Sharma 2009).

\subsubsection{Effect of reaction time}

The effect of reaction time on diazotization was studied. Variation in time was experimented from 2-10 minutes. The results obtained are presented in Fig. 5.

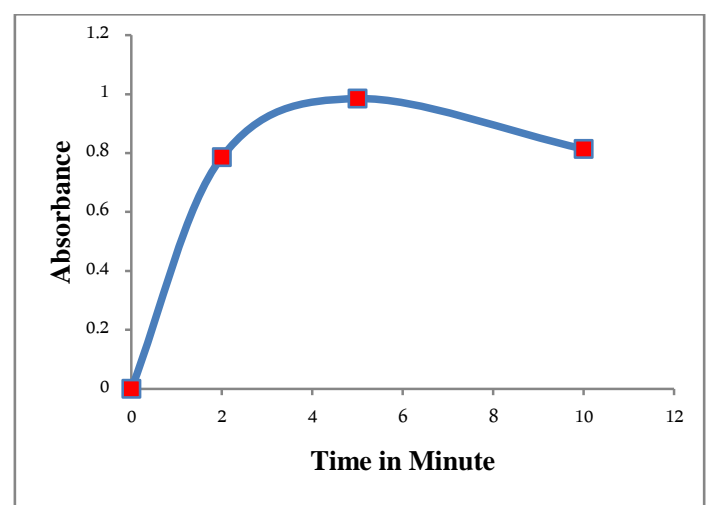

Fig. 5: Absorbance Variation with Varying Time of Diazotization

It was observed that the time required for diazotization with shaking was 5 minutes at room temperature and yellow colored azo dye stability was up to 45 minutes. Increase or decrease of the time for diazotization reaction affects the change in color intensity and absorbance value (Buddha \& Raja Ram 2009).

\subsubsection{Effect of foreign ions}

In order to assess the possible applications of the proposed method, the effect of interfering substances that often present with nitrite in complex sample matrices were studied by adding various amounts of cations and anions to $0.2 \mathrm{mg} / \mathrm{L}$ of nitrite and $0.3 \mathrm{mg} / \mathrm{L}$ of nitrate. During the interference studies, any insoluble substances that formed were simply removed by centrifugation and the 
absorbance was measured with the centrifugates. The results are given in Table 1.

Table1: Effect of Foreign Ions on the Determination of Nitrite $(0.2 \mathrm{mg} / \mathrm{L})$ and Nitrate $(0.3 \mathrm{mg} / \mathrm{L})$ Using Metoclopramide as a Reagent.

\begin{tabular}{llll}
\hline & & \multicolumn{2}{l}{ Tolerance limits $(\mathrm{mg} / \mathrm{L})$} \\
Foreign ions & Added as & Nitrite $(0.2 \mathrm{mg} / \mathrm{L})$ & Nitrate $(0.3 \mathrm{mg} / \mathrm{L})$ \\
\hline $\mathrm{Cu}^{2+}$ & $\mathrm{CuSO} \cdot 5 \mathrm{H}_{2} \mathrm{O}$ & 100 & 100 \\
$\mathrm{~K}^{+}$ & $\mathrm{KCl}$ & 1500 & 1500 \\
$\mathrm{Na}^{+}$ & $\mathrm{NaCl}$ & 200 & 200 \\
$\mathrm{Ca}^{2+}$ & $\mathrm{CaCl}_{2} \cdot 2 \mathrm{H}_{2} \mathrm{O}$ & 1000 & 50 \\
$\mathrm{Fe}^{2+}$ & $\mathrm{FeSO}_{4} \cdot 7 \mathrm{H}_{2} \mathrm{O}$ & 500 & 500 \\
$\mathrm{Cl}^{-}$ & $\mathrm{NaCl}^{2-}$ & 3000 & 3000 \\
$\mathrm{CO}_{3}{ }^{2-}$ & $\mathrm{Na}_{2} \mathrm{CO}_{3}$ & 1000 & 1000 \\
$\mathrm{HPO}_{4}{ }^{2-}$ & $\mathrm{Na}_{2} \mathrm{HPO}_{4}$ & 300 & 300 \\
$\mathrm{SO}_{4}{ }^{2-}$ & $\mathrm{Na}_{2} \mathrm{SO}_{4}$ & 1000 & 1000 \\
\hline
\end{tabular}

The results indicated that $\mathrm{K}^{+}, \mathrm{Ca}^{2+}, \mathrm{Cl}-\& \mathrm{HPO}_{4}{ }^{2}$ shown severe interference. The interference of $\mathrm{Cl}^{-}$was removed by precipitating with silver sulphate (Rodica et al. 2001, pp. 74-78). Selectivity of the proposed method was improved by converting nitrite into its azo derivative which absorbs at longer wavelength in the presence of interfering cations and anions and there tolerance limits were measured by adding ions of known concentration in the developed procedure which causes $\pm 2 \%$ relative error (Beckett \& Stenlake 2004, pp. 275-276, Veena \& Narayana 2009, pp. 89-92).

\section{The diazotization reaction}

Nitrite ion reacts with diazotizable aromatic amines such as metoclopramide in $\mathrm{HCl}$ to form diazonium ions. These ions produced strongly colored azo dyes with coupling reagent like EAA. The diazotization coupling reactions studied are shown in the Fig. 6. Metoclopramide reacts with nitrite in acidic medium to form diazonium cation which is coupled with EAA in basic media to form yellow colored azo dye (Jain et al. 1990, pp. 69-75, Pasha \& Narayana 2010, pp. 68-73).

\section{Absorption spectra}

The wavelengths of the metoclopramide, diazonium ion and yellow azo dye were investigated against suitable blank solutions. The results are shown in Fig. 7.

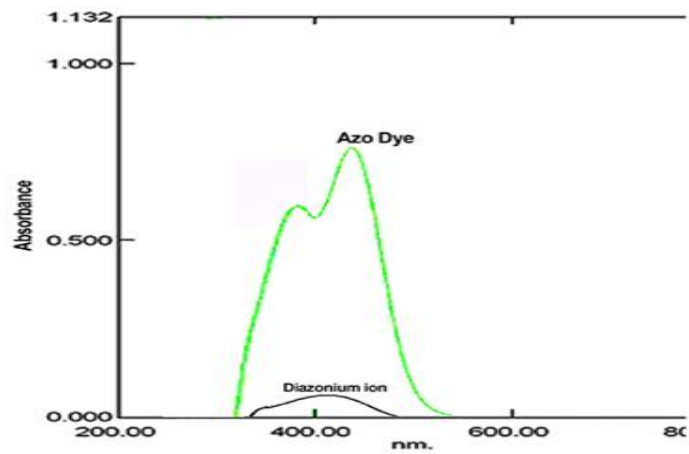

Fig. 7: Absorption Spectra of Azo Dye And Diazonium Ion.

The spectra showed that the maximum absorbance of azo dye was at $437.5 \mathrm{~nm}$ while the absorbance value for metoclopramide, diazonium ion and EAA were less than $400 \mathrm{~nm}$ and hence do not interfere in the absorbance measurement of azo dye (Sharma 2009).

\section{Calibration graph}

The calibration graph was prepared using six different levels of calibration standards from 0.01 to $0.4 \mathrm{mg} / \mathrm{L} \mathrm{NO} \mathrm{NO}_{2}-\mathrm{N}$ using 1000 $\mathrm{mg} / \mathrm{L}$ of nitrite solution. The absorbance was measured at 437.5 nm against a blank and plotted against the concentration. The results are represented in Fig. 8 below.

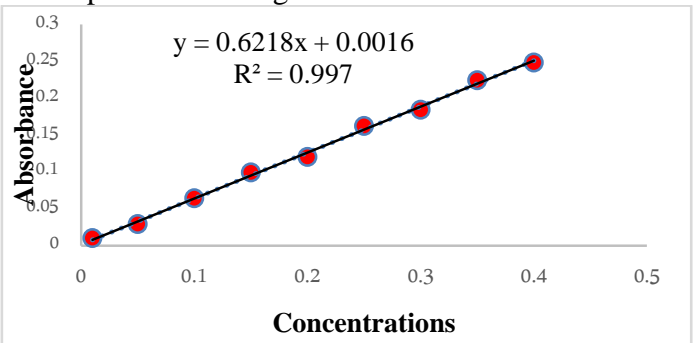

Fig. 8: The Calibration Curve of Nitrite Using Diazotization with Metoclopramide and EAA

Results showed linearity with correlation coefficient of 0.997 . Beer's law was obeyed over the range of concentrations used for the measurements. The detection limit of the diazotization based colorimetric estimation of nitrite is up to $0.004 \mathrm{mg} / \mathrm{L}$.

\section{Analytical applications}

The proposed method for the determination of nitrate and nitrite was applied on synthetic mixtures of the two ions (Table 2), and to various types of samples, viz. natural and waste waters, soil and vegetables (Table $3 \& 5$ ). The results were compared with those provided by the reference method (Pisal Method 354.1) involving sulphanilamide and $\mathrm{N}$-(1-naphthyl) ethylenediamine dihydrochloride (NEDA). The result reveals that there is close agreement between the results obtained by the proposed method and reference method for the results of water and soil samples. The results of pharmaceutical samples show that the recovery values obtained were close to $100 \%$. The recovery experiments were performed on water and soil samples in presence of $\mathrm{Cu}^{2+}, \mathrm{K}^{+}$, $\mathrm{Na}^{+}, \mathrm{Ca}^{2+}, \mathrm{Fe}^{2+}, \mathrm{Cl}^{-}, \mathrm{CO}_{3}{ }^{2-}, \mathrm{HPO}_{4}{ }^{2-}$ and $\mathrm{SO}_{4}{ }^{2-}$ etc. naturally present in the samples.

Table 2: Separation of Nitrite and Nitrate in Synthetic Laboratory Mixtures

\begin{tabular}{|c|c|c|c|c|c|}
\hline \multirow[t]{2}{*}{$\begin{array}{l}\text { Sr. } \\
\text { No. }\end{array}$} & \multirow{2}{*}{$\begin{array}{l}\text { Nitrite } \\
\text { taken } \\
\mathrm{mg} / \mathrm{L}\end{array}$} & \multirow{2}{*}{$\begin{array}{l}\text { Nitrate } \\
\text { taken } \\
\mathrm{mg} / \mathrm{L}\end{array}$} & \multirow{2}{*}{$\begin{array}{l}\text { Nitrate } \\
\text { found } \\
\mathrm{mg} / \mathrm{L}\end{array}$} & \multicolumn{2}{|c|}{ Recovery in \% } \\
\hline & & & & Nitrite & Nitrate \\
\hline 1 & 0.35 & -- & 0.344 & 98.34 & -- \\
\hline 2 & 0.3 & 0.05 & 0.296 & 98.65 & 98.46 \\
\hline 3 & 0.25 & 0.1 & 0.249 & 99.53 & 98.87 \\
\hline 4 & -- & 0.35 & 0.347 & -- & 99.12 \\
\hline
\end{tabular}

The results given in Table 3,4 \& 5 compare favorably with the reference method (Pisal Method 354.1). A statistical analysis of the results by Student's t-test at $95 \%$ confidence level showed no significant difference in accuracy and precision between proposed and reference methods. 
Table 3: Determination of Nitrite in Water and Soil Samples Using Proposed and Reference Methods $(\mathrm{N}=6)$

\begin{tabular}{|c|c|c|c|c|c|c|}
\hline \multicolumn{3}{|c|}{ Proposed method } & \multicolumn{4}{|c|}{ Reference Method (Pisal Method 354.1) } \\
\hline Sample & $\begin{array}{l}\text { Nitrite added } \\
(\mathrm{mg} / \mathrm{L})\end{array}$ & Nitrite found $(\mathrm{mg} / \mathrm{L} \pm \mathrm{SD})$ & $\%$ Recovery & Nitrite found $(\mathrm{mg} / \mathrm{L} \pm \mathrm{SD})$ & $\begin{array}{l}\% \\
\text { Recovery }\end{array}$ & t-test \\
\hline \multirow[t]{2}{*}{ Tap Water } & 0.1 & $0.093 \pm 0.003$ & 93 & $0.095 \pm 0.004$ & 95.8 & 0.0223 \\
\hline & 0.3 & $0.288 \pm 0.01$ & 96 & $0.301 \pm 0.011$ & 100.3 & 0.0689 \\
\hline \multirow[t]{3}{*}{ Surface water } & 0.1 & $0.101 \pm 0.011$ & 101.4 & $0.098 \pm 0.001$ & 98.2 & 0.2636 \\
\hline & 0.2 & $0.197 \pm 0.026$ & 98.6 & $0.204 \pm 0.021$ & 102.1 & 0.3593 \\
\hline & 0.3 & $0.291 \pm 0.01$ & 97.07 & $0.297 \pm 0.008$ & 99.1 & 0.1331 \\
\hline \multirow[t]{3}{*}{ Soil sample } & 0.1 & $0.092 \pm 0.003$ & 92 & $0.092 \pm 0.004$ & 91.6 & 0.466 \\
\hline & 0.2 & $0.188 \pm 0.006$ & 94.2 & $0.193 \pm 0.008$ & 96.3 & 0.2684 \\
\hline & 0.3 & $0.294 \pm 0.01$ & 97.93 & $0.293 \pm 0.007$ & 97.7 & 0.4695 \\
\hline
\end{tabular}

Tabulated t-value for 5 degrees of freedom at $\mathrm{P}(0.05)$ is 2.015

Table 4: Determination of Nitrite in Pharmaceutical Preparations Using Proposed and Reference Methods (N=6).

\begin{tabular}{|c|c|c|c|c|c|c|}
\hline \multirow[t]{2}{*}{ Sample } & \multirow[b]{2}{*}{ Nitrite added $(\mathrm{mg} / \mathrm{L})$} & \multirow{2}{*}{$\begin{array}{l}\text { Proposed method } \\
\text { Nitrite found } \\
(\mathrm{mg} / \mathrm{L} \pm \mathrm{SD})\end{array}$} & \multicolumn{2}{|c|}{ Reference method (Pisal Method 354.1) } & \multirow[b]{2}{*}{$\begin{array}{l}\% \\
\text { Recovery }\end{array}$} & \multirow[b]{2}{*}{ t- test } \\
\hline & & & $\begin{array}{l}\% \\
\text { Recovery }\end{array}$ & Nitrite found $(\mathrm{mg} / \mathrm{L} \pm \mathrm{SD})$ & & \\
\hline \multirow{3}{*}{$\begin{array}{l}\text { Isosorbidinitrate tablets, } \\
\text { Nichoals Piramal }\end{array}$} & 0.1 & $0.098 \pm 0.001$ & 97.8 & $0.095 \pm 0.004$ & 95.8 & 0.1373 \\
\hline & 0.2 & $0.194 \pm 0.001$ & 96.9 & $0.196 \pm 0.004$ & 97.9 & 0.1597 \\
\hline & 0.3 & $0.293 \pm 0.006$ & 97.53 & $0.299 \pm 0.006$ & 99,6 & 0.0954 \\
\hline
\end{tabular}

Tabulated t-value for 5 degrees of freedom at $\mathrm{P}(0.05)$ is 2.015

Table 5: Determination of Nitrite in Vegetable Samples Using Proposed and Reference Methods (N=6)

\begin{tabular}{|c|c|c|c|c|c|c|}
\hline \multicolumn{3}{|l|}{ Proposed method } & \multicolumn{4}{|c|}{ Reference Method (Pisal Method 354.1) } \\
\hline Sample & Nitrite added (mg/L) & Nitrite found (mg/L $\pm \mathrm{SD})$ & $\%$ Recovery & Nitrite found $(\mathrm{mg} / \mathrm{L} \pm \mathrm{SD})$ & $\%$ Recovery & t-test \\
\hline \multirow[t]{2}{*}{ Spinach } & 0.1 & $0.103 \pm 0.007$ & 103.4 & $0.104 \pm 0.005$ & 104.2 & 0.4231 \\
\hline & 0.2 & $0.189 \pm 0.005$ & 99.4 & $0.198 \pm 0.005$ & 99 & 0.4405 \\
\hline \multirow{3}{*}{ Coriander leaves } & 0.1 & $0.096 \pm 0.005$ & 95.8 & $0.101 \pm 0.005$ & 101.4 & 0.1245 \\
\hline & 0.2 & $0.189 \pm 0.005$ & 94.3 & $0.190 \pm 0.012$ & 95.2 & 0.395 \\
\hline & 0.3 & $0.293 \pm 0.007$ & 97.6 & $0.296 \pm 0.003$ & 98.5 & 0.2091 \\
\hline
\end{tabular}

Tabulated t-value for 5 degrees of freedom at $\mathrm{P}(0.05)$ is 2.015

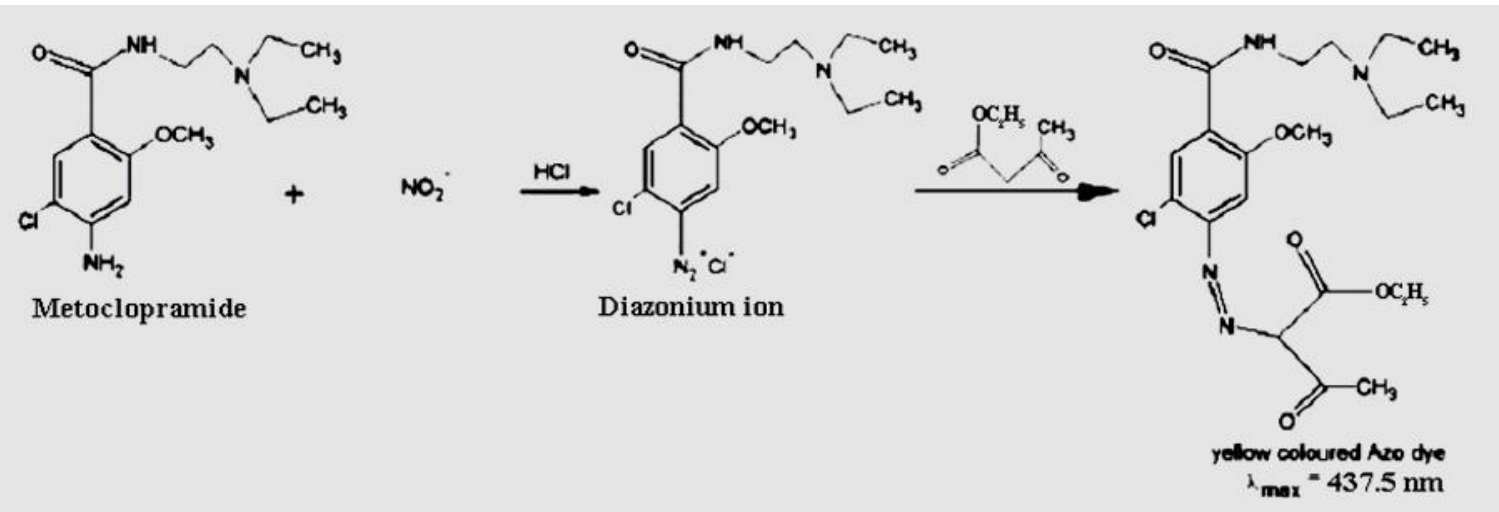

Fig. 6: Diazotization Reaction Occurring Between Nitrite and Metoclopramide and Its Coupling with EAA

\section{Conclusions}

The developed method is found to be sensitive, accurate, simple, precise and economical and can be used as an alternative to the existing methods for routine quality control analysis of nitrite in pure form, pharmaceutical preparations and environmental water, soil and food samples.

\section{Acknowledgements}

The authors are grateful to Mr. Umesh Fegade and Miss. Harsha Talele for their help in collecting and analyzing the water, soil and vegetable samples.

\section{References}

[1] Liang B, Iwatsuk M, \& Fukasawa T (1994) Catalytic spectrophotometric determination of nitrite using the chlorpromazine hydro- gen-peroxide redox reaction in acetic-acid medium. Analyst 119 (9), 2113-2117.

[2] Gray WV, \& Stephen JF, (2001) Environmental Chemistry, A Global Perspective, $1^{\text {st }}$ edn (Oxford University Press, London, UK).

[3] Cassens RG, (1995) Use of sodium nitrite in cured meats today. Food Technol 49, 72-80.

[4] Cassens RG (1997) Residual nitrite in cured meat. Food Technol. 51:53-55.

[5] Cassens RG (1999) Composition and safety of cured meats in the USA. Food Chem 59, 561-566.

[6] Ignarro LJ, Fukuto JM, Griscavage JM, Rogers NE, Byrns RE (1993) Oxidation of nitric oxide in aqueous solution to nitrite but not nitrate: comparison with enzymatically formed nitric oxide from L-arginine. Proc Natl Acad Sci USA 90, 8103-8107.

[7] Nathan C (1992) Nitric oxide as a secretary product of mammalian cells. FASEB J 6, 3051-3064.

[8] Patty EA (1963) Industrial Hygiene and Toxicology, Interscience, New York, 2, p. 917.

[9] U.S. Environmental Protection Agency Pesticides and Toxic Substances (1991) R.E.D. Facts: Inorganic nitrates/Nitrite (Sodium and Potassium Nitrates). http://www.epa.gov/oppsrrd1/REDs/factsheets/4052fact.pdf. 
[10]World Health Organization (2006) International Program on Chemical Safety, Environmental Health Criteria 5: Nitrates, Nitrites, and NNitroso Compounds. http://www.inchem.org/documents/pims/chemical/pimg016.htm.

[11]U.S. Environmental Protection Agency Ground Water and Drinking Water (2006) Consumer Factsheet on: Nitrates/Nitrites. Available at http://www.epa.gov/safewater/dwh/c-ioc/nitrates.html.

[12]Virtanen SM, et al. (1994) Nitrate and nitrite intake and the risk for type 1 diabetes in Finnish children. Childhood Diabetes in Finland Study Group. Diabet.Med 11(7), 656-662.

[13]Gupta SK, et al. (2001) recurrent diarrhea in children living in areas with high levels of nitrate in drinking water. Arch.Environ.Health 56 (4), 369-373.

[14]Gupta SK, et al. (2000) recurrent acute respiratory tract infections in areas with high nitrate concentrations in drinking water. Environ.Health Perspect. 108(4), 363-366.

[15]Ali A. Ensafi and Kazemzadeh (1999) Simultaneous determination of nitrite and nitrate in various samples using flow injection with spectrophotometric detection. Analytical Chimica Acta 382, 15-21.

[16]Murad I.H. Helaleh, Takashi Korenaga (2000) IC method for simultaneous determination of nitrate \& nitrite in human saliva. Journal of chromatography B, 744, 433-437.

[17]Hitoshi Kodamatani, Shigeo Yamazaki (2009) Selective determination method for measurement of nitrite $\&$ nitrate in water samples using high-performance liquid chromatography with post-column photochemical reaction \& chemiluminescence detection. Journal of Chromatography A 1216, 3163-3167.

[18]Vincenzo Di Matteo, Ennio Esposito (1997) Methods for the determination of nitrite by HPLC with ED. Journal of chromatography A, 789, 213-219.

[19]Keiichi Fukushi, Koji Tada , Sahori Takeda, Shin-ichi Wakida, Masataka Yamane, Kunishige Higashi (1999) Simultaneous determination of nitrate and nitrite ions in seawater by capillary zone electrophoresis using artificial seawater as the carrier solution. Journal of Chromatography A, 838 303-311

[20]Jain AK, Jahan M. and Tyagi V (1990) Construction and assessment of some percolate-selective liquid membrane electrodes. Anal. Chim. Acta. 231, 69-75.

[21] Aniruddha Pisal, Method 354.1, Water and Environmental Analysis, LAMBDA XLS and XLS+ UV -Visible Spectrophotometers, Perkin Elmer manual.

[22]APHA, (1995) Standard Methods for the Examination of Water and Waste Water, $19^{\text {th }}$ ed, American Public Health Association, Washington DC.

[23] AOAC, Method 36.1.21 (1995) 16th ed, Official Methods of Analysis, Washington, DC.

[24]Christian GD (2001) Analytical Chemistry, fifth edn, John Wiley \& Sons (Asia) Pvt. Ltd. 154

[25]Suchandra Biswas., Bhaskar Chowdhury. And Bidhan Chandra Ray (2004) A novel spectrofluorimetric method for the ultra-trace analysis of nitrite and nitrate in aqueous medium and its application to air, water, soil and forensic samples, Talenta 64, 308-312.

[26]Nidal A, Zatar, Maher A, Abu-Eid. And Abdullah FEid (1999) Spectrophotometric determination of nitrite and nitrate using phosphomolybdenum blue complex. Talenta, 50, 819-826.

[27]Wang H, Yang W, Liang SC, Zhang ZM, and Zhang HS, (2000) Spectrofluorimetric determination of nitrite with 5,6-diamino-1,3naphthalene disulfonic acid. Anal. Chim. Acta. 419, 169.

[28]Bremner JM (1965) Methods of soil analysis, part 2. C. A. Black etal. (Eds.) ASA 9, 1179.

[29]Padmarajaiah Nagaraja, Mattighatta Shivaswamy and Hemantha $\mathrm{Ku}$ mar (2002) Spectrophotometric determination of nitrate in polluted water using a new coupling reagent. Analytical Sciences, 18

[30]Chand Pasha and Narayana B (2010) A Simple Spectrophotometric Method for the Determination of Mosapride by Diazotization Method Yanbu Journal of Engineering and Science 1, 68-73.

[31]Sharma YR (2009) Elementary organic spectroscopy, S. Chand \& Company, ISBN: 81-219-2884-2.

[32]Buddha Ratna Shrestha and Raja Ram Pradhananga (2009) Spectrophotometric method for the determination of paracetamol. J. Nepal Chem. Soc. 24

[33]Rodica Diaconu, Marieta Vasilov, Gabriela Mancas (2001) Colorimetric Assay of Salivary Nitrite Content. Jurnal De Medicina Preventiva 9 (1), 74-78.

[34]Beckett AH, and Stenlake J.B., Eds. (2004) In Practical Pharmaceutical Chemistry, $4^{\text {th }}$ Edn, Part two, CBS Publication: 275, 276.

[35] Veena K. \& Narayana (2009) Spectroscopic determination of nitrite using new coupling agents. Indian Journal of Chemical Technology $16,89-92$. 